\title{
SCIDiCe
}

\author{
International Journal of Dentistry and Oral Science (IJDOS) \\ ISSN: 2377-8075
}

\section{Correlation Between Gender and Soft Tissue Characteristics Of Face Among South Indian Population Of Various Skeletal Malocclusion}

Research Article

Navaneethan ${ }^{1 *}$, Seerab Husain ${ }^{2}$, Sri Rengalakshmi ${ }^{3}$

${ }^{1}$ Reader Saveetha Dental College and Hospital, Saveetha Institute of Medical and technical Sciences, Saveetha University, Chennai, India. ${ }^{2}$ Saveetha Dental College and Hospital, Saveetha Institute of Medical and technical Sciences, Saveetha University, Chennai, India.

${ }^{3}$ Senior Lecturer Saveetha Dental College and Hospital, Saveetha Institute of Medical and technical Sciences, Saveetha University, Chennai, India.

\section{Abstract}

\begin{abstract}
Every face is unique and this variation also exists between genders. This forms the basis of sexual dimorphism. The aim of this study was to determine the correlation between gender and soft tissue of face among the south indian population. The study sample comprised 30 lateral cephalograms collected between the time period of June 2019 - March 2020, which were divided into 3 groups. FACAD software was used for the analysis of lateral cephalograms to obtain six variables, namely: glabella area (G-G1), subnasal area (A-Sn), Upper lip thickness (J-Ls), Lower lip thickness (I-Li), Labiomental sulcus thickness (B-Sm), Chin area (Pg-Pg1). The obtained results were tabulated and statistically analysed using SPSS software version 23 . One way ANOVA and post hoc tests were performed between the skeletal malocclusions. Independent $t$ - test was done to compare the variables between the two genders. The obtained results show a mean increase in all the variables of Class II except Lower lip thickness, which was maximum in Class I skeletal malocclusion. The results of One way ANOVA however, was statistically insignificant. Hence, soft tissue characteristics can provide vital information on the sexual dimorphism and also aid in the diagnosis of various malocclusions in orthodontics.
\end{abstract}

Keywords: Dimorphism; Gender; Lateral Cephalogram; Soft Tissue.

\section{Introduction}

Face is the esthetic and appealing part of the body. The first thing a person recalls from memory is the face of another person [20] Variations in the skeleton can easily be reflected by variations in the soft tissue surrounding it, due to its close proximity. Dentoskeletal structures and the facial soft tissue thickness together constitute the facial profile.

Skeletal malocclusions are the discrepancies of the skeletal structures of the face due to genetic, environmental conditions or both. It can be due to the prognathism of a specific jaw or retrognathism of the opposing jaw or a combination of both. Based on this combination, they can be classified as Class I, Class II and Class III [6, 19].
Apart from adding to the esthetic appeal to the face, the soft tissue also effectively compensates for the skeletal defects, hence masking it in minor discrepancies. The soft tissue is also affected by the position of the tooth and its inclinations. Lateral cephalogram is a supplemental aid that can be used to analyse hard and soft tissue structures 2-dimensionally [2, 4]. A well taken lateral cephalogram usually records both these structures adequately, enabling the examiner to visualize the soft tissue characteristics with ease.

There is a difference in the morphology of male and female hard and soft tissue structures. This is referred to as sexual dimorphism. Females are believed to retain most of their prepubertal traits, whereas male undergo enormous changes in terms of soft tissue characteristics as well [12]. Hence, the purpose of this study was to compare the correlation between gender and soft tissue

\section{*Corresponding Author:}

Navaneethan,

Reader Saveetha Dental College and Hospital, Saveetha Institute of Medical and technical Sciences, Saveetha University, 162, PH Road, Chennai 600077, Tamil Nadu, India. Tel: 9962787531

Email Id: navaneethan@saveetha.com

Received: February 25, 2021

Accepted: March 04, 2021

Published: March 08, 2021

Citation: Navaneethan, Seerab Husain, Sri Rengalakshmi. Correlation Between Gender and Soft Tissue Characteristics Of Face Among South Indian Population Of Various Skeletal Malocclusion. Int J Dentistry Oral Sci. 2021;08(03):1899-1905. doi: http://dx.doi.org/10.19070/2377-8075-21000377

Copyright: Navaneethan ${ }^{\circ} 2021$. This is an open-access article distributed under the terms of the Creative Commons Attribution License, which permits unrestricted use, distribution and reproduction in any medium, provided the original author and source are credited. 
characteristics of various skeletal malocclusions of the south indian population.

\section{Materials and Methods}

The retrospective study consisted of 30 lateral cephalograms, collected between the time period of June 2019 - March 2020. These lateral cephalograms were divided into 3 groups, namely:

Group A - Class I skeletal pattern.

Group B - Class II skeletal pattern.

Group C - Class III skeletal pattern.

Each group contained 10 radiographs, pertaining to their skeletal relationship. The data was collected from the Saveetha Institute of Medical and Technical Sciences (SIMATS) university data- base. Ethical approval was obtained from the institutional review board. FACAD software was used for analysis of the lateral cephalograms. Points were plotted using this software to obtain linear measurements. The plotted points were verified and approved by the other authors. The following variables were taken into consideration:

Glabella Area : G-G1

Subnasal Area : A-Sn

Upper Lip Thickness : J-Ls

Lower Lip Thickness : I-Li

Labiomental Sulcus Thickness : B-Sm

Chin Area : Pg-Pg1

Linear measurements of all the aforementioned variables were obtained. The obtained results were subjected to statistical analysis using SPSS software version 23. One way ANOVA, post hoc and Bonferroni tests were performed to compare the variables

Table 1. Descriptive statistics showing mean and standard deviation between malocclusions.

\begin{tabular}{|c|c|c|c|c|c|c|c|c|c|}
\hline \multicolumn{10}{|c|}{ Descriptives } \\
\hline & & \multirow{2}{*}{$\mathbf{N}$} & \multirow{2}{*}{ Mean } & \multirow{2}{*}{$\begin{array}{l}\text { Std. Devia- } \\
\text { tion }\end{array}$} & \multirow{2}{*}{ Std. Error } & \multicolumn{2}{|c|}{$\begin{array}{l}95 \% \text { Confidence } \\
\text { Interval for Mean }\end{array}$} & \multirow{2}{*}{$\begin{array}{l}\text { Mini- } \\
\text { mum }\end{array}$} & \multirow{2}{*}{$\begin{array}{l}\text { Maxi- } \\
\text { mum }\end{array}$} \\
\hline & & & & & & $\begin{array}{l}\text { Lower } \\
\text { Bound }\end{array}$ & $\begin{array}{l}\text { Upper } \\
\text { Bound }\end{array}$ & & \\
\hline \multirow{4}{*}{$G-G^{*}$} & Class I & 10 & 5.270 & 0.9866 & 0.3120 & 4.564 & 5.976 & 3.7 & 6.8 \\
\hline & Class II & 10 & 5.510 & 1.0082 & 0.3188 & 4.789 & 6.231 & 4.2 & 6.8 \\
\hline & Class III & 10 & 4.010 & 1.1070 & 0.3501 & 3.218 & 4.802 & 2.4 & 5.5 \\
\hline & Total & 30 & 4.930 & 1.2023 & 0.2195 & 4.481 & 5.379 & 2.4 & 6.8 \\
\hline \multirow{4}{*}{$\mathrm{A}-\mathrm{Sn}^{* *}$} & Class I & 10 & 13.890 & 3.3017 & 1.0441 & 11.528 & 16.252 & 7.2 & 18.8 \\
\hline & Class II & 10 & 14.850 & 1.7784 & 0.5624 & 13.578 & 16.122 & 12.7 & 18.0 \\
\hline & Class III & 10 & 13.720 & 4.5672 & 1.4443 & 10.453 & 16.987 & 7.3 & 20.0 \\
\hline & Total & 30 & 14.153 & 3.3308 & 0.6081 & 12.910 & 15.397 & 7.2 & 20 \\
\hline \multirow{4}{*}{$\mathrm{J}-\mathrm{Ls}^{* * *}$} & Class I & 10 & 7.320 & 1.3323 & 0.4213 & 6.367 & 8.273 & 4.7 & 9.2 \\
\hline & Class II & 10 & 9.410 & 2.9335 & 0.9277 & 7.311 & 11.509 & 6.2 & 15.8 \\
\hline & Class III & 10 & 9.000 & 3.0467 & 0.9634 & 6.821 & 11.179 & 5.1 & 13.0 \\
\hline & Total & 30 & 8.577 & 2.6359 & 0.4813 & 7.592 & 9.561 & 4.7 & 15.8 \\
\hline \multirow{4}{*}{$\mathrm{I}-\mathrm{Li}^{* * * *}$} & Class I & 10 & 11.650 & 2.5247 & 0.7984 & 9.844 & 13.456 & 7.4 & 15.2 \\
\hline & Class II & 10 & 11.620 & 2.1343 & 0.6749 & 10.093 & 13.147 & 7.8 & 14.2 \\
\hline & Class III & 10 & 10.360 & 3.3450 & 1.0578 & 7.967 & 12.753 & 5.9 & 14.3 \\
\hline & Total & 30 & 11.210 & 2.6904 & 0.4912 & 10.205 & 12.215 & 5.9 & 15.2 \\
\hline \multirow{4}{*}{ B-Sm ${ }^{* * * * *}$} & Class I & 10 & 10.830 & 1.9351 & 0.6119 & 9.446 & 12.214 & 6.9 & 13.8 \\
\hline & Class II & 10 & 13.110 & 3.3418 & 1.0568 & 10.719 & 15.501 & 8.1 & 18.8 \\
\hline & Class III & 10 & 8.970 & 2.6094 & 0.8252 & 7.103 & 10.837 & 4.6 & 11.9 \\
\hline & Total & 30 & 10.970 & 3.1155 & 0.5688 & 9.807 & 12.133 & 4.6 & 18.8 \\
\hline \multirow{4}{*}{$\mathrm{Pg}-\mathrm{Pg}^{3 * * * * * *}$} & Class I & 10 & 10.210 & 2.5519 & 0.8070 & 8.384 & 12.036 & 6.6 & 13.5 \\
\hline & Class II & 10 & 11.060 & 2.1849 & 0.6909 & 9.497 & 12.623 & 7.3 & 14.1 \\
\hline & Class III & 10 & 8.550 & 2.5864 & 0.8179 & 6.700 & 10.400 & 4.8 & 11.5 \\
\hline & Total & 30 & 9.940 & 2.5889 & 0.4727 & 8.973 & 10.907 & 4.8 & 14.1 \\
\hline & & & & ${ }^{*} \mathbf{G} \mathbf{1}$ & $\begin{array}{l}\text { lla area } \\
\text { lasal area } \\
\text { er lip thickne } \\
\text { ver lip thickne } \\
\text { biomental sul }\end{array}$ & thickness & & & \\
\hline
\end{tabular}


between malocclusion. Independent $\mathrm{T}$ test was done between genders to compare their soft tissue characteristics of face.

\section{Results and Discussion}

The descriptive statistics showing the mean and standard deviation of the variables within the malocclusion is depicted in (Table 1). Class II skeletal group showed the maximum thickness of all the soft tissue variables, except Lower lip thickness (I-Li), which is shown to be thickest in Class I skeletal groups. Class III skeletal pattern exhibited the least thickness of soft tissue characteristics of the face.

The mean and standard deviation of variables between gender is shown in (Table 2). Males showed increased thickness of all the variables except soft tissue gonion and pogonion thickness, which were thicker in females.

The results for One way ANOVA is shown in (Table 3). When comparing the groups between each other, the results were insignificant.

(Table 4,5,6) show the results for independent $t$ - test, which are statistically insignificant.

Previously, our team had conducted numerous clinical trials (Samantha et al., 2017) [23] , in vitro studies [15, 18, 22, 8, 9, 28, 27], Finite element studies $[13,17,26]$ and a couple of prospective studies $[7,8,9,10,11,21]$. Over the past 5 years. Now we are focusing on this retrospective study, done with the data obtained from our vast database. The idea for this study stemmed from the current interest in our community on the soft tissue paradigm shift.

Orthodontic treatment has always been directed towards the treatment of the face, rather than the skeleton. Although skeletal tissues are also considered important, the final outlook of the soft tissue dictates the success/failure of the treatment [3]. This study was aimed at providing a standard for male and female soft tissue characteristics, as it will aid in the diagnosis and effective treatment planning. The soft tissue in conjecture with the hard tissue norms are helpful in establishing ideal facial esthetics and occlusion [14].

The finding of our retrospective study shows that the thickness of glabella, subnasale, upper lip, labiomental sulcus and chin are maximum in Class II skeletal pattern, followed by Class I skeletal pattern. Lower lip thickness however, is thickest in Class I skeletal pattern, followed by Class II skeletal pattern. Class III showed the least thickness of all the variables. This is in accordance to the results reported by Perovic et al., in his research [20]. When comparing genders, the thickness of gonion and pogonion is more in females compared to males. This is in agreement with the studies conducted in the north indian population [24]. The results when subjected to One way ANOVA and independent $t$ tests to compare the variables among the other groups and between the gender, yielded statistically insignificant results.

Radiographs can be a valuable aid in diagnosis of a malocclusion. It is easily accessible and can be transferred over the internet. OPGs and CBCT also aid in the ease of implant placements and planning for any sort of implants. They are vital in ruling out individual tooth anomalies as well that might hinder orthodontic tooth movement.

Lateral cephalograms have become a routine in the daily orthodontic practice. Many skeletal discrepancies are precisely diagnosed using lateral cephalometric analysis. The analysis of vertebrae and sella turcica dimensions have also been shown to have diagnostic relevance. Similarly, angular photogrammetric analysis

Table 2. Descriptive statistics showing mean and standard deviation between genders.

\begin{tabular}{|c|c|c|c|c|c|}
\hline \multicolumn{6}{|c|}{ Group Statistics } \\
\hline & Sex & $\mathbf{N}$ & Mean & $\begin{array}{c}\text { Std. Devia- } \\
\text { tion }\end{array}$ & $\begin{array}{c}\text { Std. Error } \\
\text { Mean }\end{array}$ \\
\hline \multirow{2}{*}{$G-G^{*}$} & Male & 15 & 4.860 & 1.2141 & 0.3135 \\
\hline & Female & 15 & 5.000 & 1.2288 & 0.3173 \\
\hline \multirow{2}{*}{$\mathrm{A}-\mathrm{Sn}^{* *}$} & Male & 15 & 14.520 & 3.6163 & 0.9337 \\
\hline & Female & 15 & 13.787 & 3.1009 & 0.8006 \\
\hline \multirow{2}{*}{$\mathrm{J}-\mathrm{Ls}^{* * *}$} & Male & 15 & 9.153 & 3.0064 & 0.7762 \\
\hline & Female & 15 & 8.00 & 2.1544 & 0.5563 \\
\hline \multirow{2}{*}{$\mathrm{I}-\mathrm{Li}^{* * * *}$} & Male & 15 & 11.640 & 2.9354 & 0.7579 \\
\hline & Female & 15 & 10.780 & 2.4455 & 0.6314 \\
\hline \multirow{2}{*}{ B-Sm ${ }^{* * * * *}$} & Male & 15 & 11.327 & 3.4654 & 0.8948 \\
\hline & Female & 15 & 10.613 & 2.7972 & 0.7222 \\
\hline \multirow{2}{*}{$P g-\mathrm{Pg}^{* * * * * *}$} & Male & 15 & 9.327 & 2.2789 & 0.5884 \\
\hline & Female & 15 & 10.553 & 2.8079 & 0.7250 \\
\hline & & & $\begin{array}{l}\text { lla area } \\
\text { lasal area } \\
\text { er lip thic } \\
\text { ver lip thi } \\
\text { biomenta }\end{array}$ & $\begin{array}{l}\text { ss } \\
\text { ess } \\
\text { cus thickness }\end{array}$ & \\
\hline
\end{tabular}


Table 3. Compare between three malocclusions by One way ANOVA.

\begin{tabular}{|c|c|c|c|c|c|c|}
\hline \multicolumn{7}{|c|}{ ANOVA } \\
\hline & & $\begin{array}{l}\text { Sum of } \\
\text { Squares }\end{array}$ & df & $\begin{array}{l}\text { Mean } \\
\text { Square }\end{array}$ & $\mathbf{F}$ & Sig. \\
\hline \multirow{3}{*}{ G-G' } & Between Groups & 12.984 & 2 & 6.492 & 6.057 & $.007^{*}$ \\
\hline & Within Groups & 28.939 & 27 & 1.072 & & \\
\hline & Total & 41.923 & 29 & & & \\
\hline \multirow{3}{*}{$\mathrm{A}-\mathrm{Sn}$} & Between Groups & 7.425 & 2 & 3.712 & 0.319 & $.730^{* *}$ \\
\hline & Within Groups & 314.310 & 27 & 11.641 & & \\
\hline & Total & 321.735 & 29 & & & \\
\hline \multirow{3}{*}{ J-Ls } & Between Groups & 24.529 & 2 & 12.264 & 1.871 & $.173^{* *}$ \\
\hline & Within Groups & 176.965 & 27 & 6.554 & & \\
\hline & Total & 201.494 & 29 & & & \\
\hline \multirow{3}{*}{ I-Li } & Between Groups & 10.842 & 2 & 5.421 & 0.735 & $.489^{* *}$ \\
\hline & Within Groups & 199.065 & 27 & 7.373 & & \\
\hline & Total & 209.907 & 29 & & & \\
\hline \multirow{3}{*}{ B-Sm } & Between Groups & 85.992 & 2 & 42.996 & 5.938 & $.007^{*}$ \\
\hline & Within Groups & 195.491 & 27 & 7.240 & & \\
\hline & Total & 281.483 & 29 & & & \\
\hline \multirow{3}{*}{ Pg-Pg' } & Between Groups & 32.594 & 2 & 16.297 & 2.72 & $.084^{* *}$ \\
\hline & Within Groups & 161.778 & 27 & 5.992 & & \\
\hline & Total & 194.372 & 29 & & & \\
\hline
\end{tabular}

${ }^{*}$ Glabella area and labiomental sulcus thickness show statistical significance between three groups, as $\mathrm{p}$ value is $<0.05$.

${ }^{* *}$ Subnasal area, Upper lip thickness, Lower lip thickness show statistical insignificance between three groups, as $\mathrm{p}$ value is $>0.05$.

have also been shown to produce reliable results in aiding the diagnosis of soft tissue deviations. This study could also be used as one such adjunct to the growing arsenal of diagnostic aids [25].

Kamalpreet et al., in his study has made use of MRI and CBCT to evaluate the soft tissue characteristics of the north east indian population [16]. Atashi et al. and Chen et al. have also reported changes in the thickness of soft tissue characters in males and females. They have cited these differences to be due to differences in their body mass index (BMI). Aggarwal et al., in his study has recommended the use of the soft tissue characteristics and variations in orthodontic treatment planning as they seemed to have significant clinical implications [1].

Soft tissue variations can be attributed to a variety of influencing factors, out of which gender is one such cause. The role of hormones such as testosterone in men which facilitates collagen formation, causing thicker soft tissue and estrogen in women, which decreases collagen formation due to the activity of hyaluronic acid, causing reduction in the soft tissue thickness, is noteworthy [5]. Further more, improving knowledge on the sexual dimorphism that exists between both the genders in terms of their soft tissue characteristics can aid one to formulate an effective treatment plan, that caters to the patients optimum requirements and establish a standard protocol of treatment.

\section{Conclusion}

With in the limits of the study it was concluded that establishment of a norm for soft tissue characteristics was the need of the hour as it can still provide vital clues in providing quality orthodontic therapy to the patients, by keeping the soft tissue structures ahead of the priority list.

\section{References}

[1]. Aggarwal I, Singla A. Soft tissue cephalometric analysis applied to Himachali ethnic population. Indian Journal of Dental Sciences. 2016 Jul 1;8(3):124.

[2]. Al-Azemi R, Al-Jame B, Årtun J. Lateral cephalometric norms for adolescent Kuwaitis: soft tissue measurements. Medical Principles and Practice. 2008;17(3):215-20.

[3]. AlBarakati SF. Soft tissue facial profile of adult Saudis. Saudi Med J. 2011;32(8):836-42.

[4]. Al-Jame B, Artun J, Al-Azemi R, Behbehani F, Buhamra S. Lateral cephalometric norms for adolescent Kuwaitis: hard tissue measurements. Med Princ Pract. 2006;15(2):91-7. Pubmed PMID: 16484833.

[5]. Al-Mashhadany SM, Al-Chalabi HM, Nahidh M. Evaluation of facial soft tissue thickness in normal adults with different vertical discrepancies. Int J Sci Res. 2017;6(2):938-42.

[6]. Ardani IGAW, Willyanti I, Narmada IB. Correlation between vertical components and skeletal Class II malocclusion in ethnic Javanese. Clin Cosmet Investig Dent. 2018 Dec 19;10:297-302. Pubmed PMID: 30588125.

[7]. Dinesh SP, Arun AV, Sundari KK, Samantha C, Ambika K. An indigenously designed apparatus for measuring orthodontic force. J Clin Diagn Res. 2013 Nov;7(11):2623-6. Pubmed PMID: 24392423.

[8]. Felicita AS. Orthodontic management of a dilacerated central incisor and partially impacted canine with unilateral extraction - A case report. Saudi Dent J. 2017 Oct;29(4):185-193. Pubmed PMID: 29033530,

[9]. Felicita AS. Quantification of intrusive/retraction force and moment generated during en-masse retraction of maxillary anterior teeth using mini-implants: A conceptual approach. Dental Press J Orthod. 2017 SepOct:22(5):47-55. Pubmed PMID: 29160344.

[10]. Felicita AS, Chandrasekar S, Shanthasundari KK. Determination of craniofacial relation among the subethnic Indian population: a modified approach - (Sagittal relation). Indian J Dent Res. 2012 May-Jun;23(3):305-12. Pubmed PMID: 23059564. 
Table 4. Independent $\mathrm{t}$ test between the genders of Class I malocclusion.

\begin{tabular}{|c|c|c|c|c|c|c|c|c|c|c|}
\hline \multicolumn{11}{|c|}{ Independent Samples Test } \\
\hline & & \multicolumn{2}{|c|}{$\begin{array}{l}\text { Levene's } \\
\text { Test for } \\
\text { Equality of } \\
\text { Variances }\end{array}$} & \multicolumn{7}{|c|}{ t-test for Equality of Means } \\
\hline & & \multirow[t]{2}{*}{$\mathrm{F}$} & \multirow[t]{2}{*}{ Sig. } & \multirow[t]{2}{*}{$\mathrm{t}$} & \multirow[t]{2}{*}{ df } & \multirow[t]{2}{*}{$\begin{array}{c}\text { Sig. } \\
\text { (2-tailed) }\end{array}$} & \multirow[t]{2}{*}{$\begin{array}{l}\text { Mean } \\
\text { Differ- } \\
\text { ence }\end{array}$} & \multirow{2}{*}{$\begin{array}{l}\text { Std. } \\
\text { Error } \\
\text { Differ- } \\
\text { ence }\end{array}$} & \multicolumn{2}{|c|}{$\begin{array}{c}95 \% \text { Confidence } \\
\text { Interval of the Dif- } \\
\text { ference }\end{array}$} \\
\hline & & & & & & & & & Lower & Upper \\
\hline \multirow[t]{2}{*}{ G-G' } & $\begin{array}{c}\text { Equal variances as- } \\
\text { sumed }\end{array}$ & 0.303 & $.597^{*}$ & -1.145 & 8 & 0.285 & -0.7167 & 0.6262 & -2.1606 & 0.7273 \\
\hline & $\begin{array}{c}\text { Equal variances not } \\
\text { assumed }\end{array}$ & & & -1.114 & 5.981 & 0.308 & -0.7167 & 0.6434 & -2.2922 & 0.8589 \\
\hline \multirow[t]{2}{*}{ A-Sn } & $\begin{array}{c}\text { Equal variances as- } \\
\text { sumed }\end{array}$ & 3.683 & $.091^{*}$ & 0.214 & 8 & 0.836 & 0.4833 & 2.2540 & -4.7145 & 5.6811 \\
\hline & $\begin{array}{c}\text { Equal variances not } \\
\text { assumed }\end{array}$ & & & 0.257 & 6.478 & 0.806 & 0.4833 & 1.8843 & -4.0461 & 5.0128 \\
\hline \multirow[t]{2}{*}{ J-Ls } & $\begin{array}{c}\text { Equal variances as- } \\
\text { sumed }\end{array}$ & 2.369 & $.162^{*}$ & 1.296 & 8 & 0.231 & 1.0750 & 0.8292 & -0.8372 & 2.9872 \\
\hline & $\begin{array}{c}\text { Equal variances not } \\
\text { assumed }\end{array}$ & & & 1.153 & 4.309 & 0.309 & 1.0750 & 0.9324 & -1.4423 & 3.5923 \\
\hline \multirow[t]{2}{*}{ I-Li } & $\begin{array}{c}\text { Equal variances as- } \\
\text { sumed }\end{array}$ & 1.183 & $.308^{*}$ & 0.591 & 8 & 0.571 & 1.0000 & 1.6920 & -2.9017 & 4.9017 \\
\hline & $\begin{array}{c}\text { Equal variances not } \\
\text { assumed }\end{array}$ & & & 0.650 & 8.000 & 0.534 & 1.0000 & 1.5381 & -2.5468 & 4.5468 \\
\hline \multirow[t]{2}{*}{ B-Sm } & $\begin{array}{c}\text { Equal variances as- } \\
\text { sumed }\end{array}$ & 0.295 & $.602^{*}$ & -1.353 & 8 & 0.213 & -1.6167 & 1.1952 & -4.3729 & 1.1395 \\
\hline & $\begin{array}{c}\text { Equal variances not } \\
\text { assumed }\end{array}$ & & & -1.324 & 6.104 & 0.233 & -1.6167 & 1.2212 & -4.5925 & 1.3592 \\
\hline \multirow[t]{2}{*}{$\mathrm{Pg}-\mathrm{Pg}$} & $\begin{array}{c}\text { Equal variances as- } \\
\text { sumed }\end{array}$ & 0.175 & $.687^{*}$ & -0.755 & 8 & 0.472 & -1.2750 & 1.6880 & -5.1675 & 2.6175 \\
\hline & $\begin{array}{c}\text { Equal variances not } \\
\text { assumed }\end{array}$ & & & -0.799 & 7.680 & 0.448 & -1.2750 & 1.5962 & -4.9828 & 2.4328 \\
\hline
\end{tabular}

[11]. Felicita AS. Orthodontic extrusion of Ellis Class VIII fracture of maxillary lateral incisor - The sling shot method. Saudi Dent J. 2018 Jul;30(3):265269. Pubmed PMID: 29942113.

[12]. Hsiao TH, Tsai SM, Chou ST, Pan JY, Tseng YC, Chang HP, et al. Sex determination using discriminant function analysis in children and adolescents: a lateral cephalometric study. Int J Legal Med. 2010 Mar;124(2):155-60. Pubmed PMID: 20094724

[13]. Jain RK, Kumar SP, Manjula WS. Comparison of intrusion effects on maxillary incisors among mini implant anchorage, j-hook headgear and utility arch. J Clin Diagn Res. 2014 Jul;8(7):ZC21-4. Pubmed PMID: 25177631.

[14]. Kamak H, Celikoglu M. Facial soft tissue thickness among skeletal malocclusions: is there a difference? Korean J Orthod. 2012 Feb;42(1):23-31. Pubmed PMID: 23112928

[15]. Kamisetty SK, Verma JK, Arun, Sundari S, Chandrasekhar S, Kumar A. SBS vs Inhouse Recycling Methods-An Invitro Evaluation. J Clin Diagn Res. 2015 Sep;9(9):ZC04-8. . Pubmed PMID: 26501002.

[16]. Kaur K, Sehrawat JS, Bahadur R. Sex dependent variations in craniofacial soft-tissue thicknesses estimated from MRI and CT scans: A pilot study based on Northwest Indian subjects. Int J Diagn Imaging. 2017;4:47.

[17]. Pandian KS, Krishnan S, Kumar SA. Angular photogrammetric analysis of the soft-tissue facial profile of Indian adults. Indian J Dent Res. $2018 \mathrm{Mar}-$ Apr;29(2):137-143.Pubmed PMID: 29652003.

[18]. Krishnan S, Saravana Pandian AK. Effect of bisphosphonates on orthodontic tooth movement - an update. Journal of clinical and diagnostic research: JCDR. 2015 Apr;9(4):ZE01.
[19]. Mahendran, S. 'Status of malocclusion among adults in rural areas'.International Journal of Current Advanced Research. 2017;2958-2960. doi: 10.24327/ijcar.2017.2960.0153.

[20]. Perović T, Blažej Z. Male and Female Characteristics of Facial Soft Tissue Thickness in Different Orthodontic Malocclusions Evaluated by Cephalometric Radiography. Med Sci Monit. 2018 May 23;24:3415-3424. Pubmed PMID: 29791323.

[21]. Ramesh Kumar KR, Shanta Sundari KK, Venkatesan A, Chandrasekar S. Depth of resin penetration into enamel with 3 types of enamel conditioning methods: a confocal microscopic study. Am J Orthod Dentofacial Orthop. 2011 Oct;140(4):479-85. Pubmed PMID: 21967934.

[22]. Rubika J, Sumathi Felicita A, Sivambiga V. Gonial angle as an indicator for the prediction of growth pattern. World Journal of Dentistry. 2015;6(3):1613.

[23]. Samantha C, Sundari S, Chandrasekhar S, Sivamurty G, Dinesh S. Comparative evaluation of two Bis-GMA based orthodontic bonding adhesives-A randomized clinical trial. Journal of clinical and diagnostic research: JCDR. 2017 Apr;11(4):ZC40

[24]. Saxena T, Panat SR, Sangamesh NC, Choudhary A, Aggarwal A, Yadav N. Facial soft tissue thickness in North Indian adult population. Journal of Indian Academy of Oral Medicine and Radiology. 2012 Apr 1;24(2):121.

[25]. Scribante A, Sfondrini MF, Cassani M, Fraticelli D, Beccari S, Gandini P. Sella turcica bridging and dental anomalies: is there an association? Int J Paediatr Dent. 2017 Nov;27(6):568-573. Pubmed PMID: 28387468.

[26]. Sivamurthy G, Sundari S. Stress distribution patterns at mini-implant site 
Table 5. Independent $t$ test between the genders of Class II malocclusion.

\begin{tabular}{|c|c|c|c|c|c|c|c|c|c|c|}
\hline \multicolumn{11}{|c|}{ Independent Samples Test } \\
\hline & & \multicolumn{2}{|c|}{$\begin{array}{c}\text { Levene's Test } \\
\text { for Equality of } \\
\text { Variances } \\
\end{array}$} & \multicolumn{7}{|c|}{ t-test for Equality of Means } \\
\hline & & \multirow[t]{2}{*}{$\mathbf{F}$} & \multirow[t]{2}{*}{ Sig. } & \multirow[t]{2}{*}{$\mathbf{t}$} & \multirow[t]{2}{*}{ df } & \multirow[t]{2}{*}{$\begin{array}{c}\text { Sig. } \\
\text { (2-tailed) }\end{array}$} & \multirow[t]{2}{*}{$\begin{array}{c}\text { Mean } \\
\text { Differ- } \\
\text { ence }\end{array}$} & \multirow{2}{*}{$\begin{array}{l}\text { Std. } \\
\text { Error } \\
\text { Differ- } \\
\text { ence }\end{array}$} & \multicolumn{2}{|c|}{$\begin{array}{l}95 \% \text { Confidence } \\
\text { Interval of the Dif- } \\
\text { ference }\end{array}$} \\
\hline & & & & & & & & & Lower & Upper \\
\hline \multirow[b]{2}{*}{ G-G' } & $\begin{array}{c}\text { Equal } \\
\text { variances } \\
\text { assumed }\end{array}$ & 0.000 & $.991^{*}$ & 0.790 & 8 & 0.453 & 0.5250 & 0.6649 & -1.0082 & 2.0582 \\
\hline & $\begin{array}{l}\text { Equal } \\
\text { variances } \\
\text { not as- } \\
\text { sumed }\end{array}$ & & & 0.782 & 6.374 & 0.462 & 0.5250 & 0.6710 & -1.0939 & 2.1439 \\
\hline \multirow[b]{2}{*}{ A-Sn } & $\begin{array}{c}\text { Equal } \\
\text { variances } \\
\text { assumed }\end{array}$ & 0.787 & $.401^{*}$ & 1.779 & 8 & 0.113 & 1.8333 & 1.0307 & -0.5435 & 4.2102 \\
\hline & $\begin{array}{l}\text { Equal } \\
\text { variances } \\
\text { not as- } \\
\text { sumed }\end{array}$ & & & 1.580 & 4.292 & 0.184 & 1.8333 & 1.1604 & -1.3038 & 4.9705 \\
\hline \multirow[b]{2}{*}{ J-Ls } & $\begin{array}{c}\text { Equal } \\
\text { variances } \\
\text { assumed }\end{array}$ & 1.886 & $.207^{*}$ & 1.209 & 8 & 0.261 & 2.2333 & 1.8467 & -2.0252 & 6.4918 \\
\hline & $\begin{array}{c}\text { Equal } \\
\text { variances } \\
\text { not as- } \\
\text { sumed }\end{array}$ & & & 1.068 & 4.212 & 0.343 & 2.2333 & 2.0902 & -3.4566 & 7.9232 \\
\hline \multirow[b]{2}{*}{$\mathrm{I}-\mathrm{Li}$} & $\begin{array}{c}\text { Equal } \\
\text { variances } \\
\text { assumed }\end{array}$ & 3.793 & $.087^{*}$ & 1.660 & 8 & 0.136 & 2.0917 & 1.2603 & -0.8146 & 4.9979 \\
\hline & $\begin{array}{l}\text { Equal } \\
\text { variances } \\
\text { not as- } \\
\text { sumed }\end{array}$ & & & 1.986 & 6.462 & 0.091 & 2.0917 & 1.0530 & -0.4410 & 4.6243 \\
\hline \multirow[b]{2}{*}{ B-Sm } & $\begin{array}{c}\text { Equal } \\
\text { variances } \\
\text { assumed }\end{array}$ & 1.603 & $.241^{*}$ & 2.247 & 8 & 0.055 & 4.0250 & 1.7916 & -0.1064 & 8.1564 \\
\hline & $\begin{array}{c}\text { Equal } \\
\text { variances } \\
\text { not as- } \\
\text { sumed }\end{array}$ & & & 2.107 & 5.217 & 0.087 & 4.0250 & 1.9104 & -0.8249 & 8.8749 \\
\hline \multirow[b]{2}{*}{ Pg-Pg' } & $\begin{array}{c}\text { Equal } \\
\text { variances } \\
\text { assumed }\end{array}$ & 0.488 & $.505^{*}$ & -1.617 & 8 & 0.145 & -2.1000 & 1.2986 & -5.0947 & 0.8947 \\
\hline & $\begin{array}{c}\text { Equal } \\
\text { variances } \\
\text { not as- } \\
\text { sumed }\end{array}$ & & & -1.557 & 5.755 & 0.172 & -2.1000 & 1.3485 & -5.4339 & 1.2339 \\
\hline
\end{tabular}

*there is no statistical significance between the variables in Class II as the p value is $>0.05$.

during retraction and intrusion--a three-dimensional finite element study. Prog Orthod. 2016;17:4. Pubmed PMID: 26780464.

[27]. Vikram NR, Prabhakar R, Kumar SA, Karthikeyan MK, Saravanan R. Ball Headed Mini Implant. Journal of clinical and diagnostic research: JCDR. 2017 Jan;11(1):ZL02.
[28]. Viswanath A, Ramamurthy J, Dinesh SP, Srinivas A. Obstructive sleep apnea: awakening the hidden truth. Niger J Clin Pract. 2015 Jan-Feb;18(1):1-7. Pubmed PMID: 25511335. 
Table 6. Independent $t$ test between the genders of Class III malocclusion.

\begin{tabular}{|c|c|c|c|c|c|c|c|c|c|c|}
\hline \multicolumn{11}{|c|}{ Independent Samples Test } \\
\hline & & \multicolumn{2}{|c|}{$\begin{array}{c}\text { Levene's Test for } \\
\text { Equality of Vari- } \\
\text { ances }\end{array}$} & \multicolumn{7}{|c|}{ t-test for Equality of Means } \\
\hline & & \multirow[t]{2}{*}{$\mathbf{F}$} & \multirow[t]{2}{*}{ Sig. } & \multirow[t]{2}{*}{$\mathbf{t}$} & \multirow[t]{2}{*}{ df } & \multirow[t]{2}{*}{$\begin{array}{l}\text { Sig. } \\
\text { (2-tailed) }\end{array}$} & \multirow{2}{*}{$\begin{array}{l}\text { Mean } \\
\text { Differ- } \\
\text { ence }\end{array}$} & \multirow{2}{*}{$\begin{array}{l}\text { Std. Er- } \\
\text { ror Dif- } \\
\text { ference }\end{array}$} & \multicolumn{2}{|c|}{$\begin{array}{l}95 \% \text { Confidence Interval } \\
\text { of the Difference }\end{array}$} \\
\hline & & & & & & & & & Lower & Upper \\
\hline \multirow[t]{2}{*}{ G-G' } & $\begin{array}{c}\text { Equal } \\
\text { variances } \\
\text { assumed }\end{array}$ & 0.159 & $.701^{* *}$ & -0.189 & 8 & 0.855 & -0.1400 & 0.7409 & -1.8486 & 1.5686 \\
\hline & $\begin{array}{l}\text { Equal vari- } \\
\text { ances not } \\
\text { assumed }\end{array}$ & & & -0.189 & 7.929 & 0.855 & -0.1400 & 0.7409 & -1.8513 & 1.5713 \\
\hline \multirow[t]{2}{*}{ A-Sn } & $\begin{array}{c}\text { Equal } \\
\text { variances } \\
\text { assumed }\end{array}$ & 0.988 & $.349 * *$ & 0.118 & 8 & 0.909 & 0.3600 & 3.0611 & -6.6990 & 7.4190 \\
\hline & $\begin{array}{l}\text { Equal vari- } \\
\text { ances not } \\
\text { assumed }\end{array}$ & & & 0.118 & 7.397 & 0.910 & 0.3600 & 3.0611 & -6.8005 & 7.5205 \\
\hline \multirow[t]{2}{*}{ J-Ls } & $\begin{array}{c}\text { Equal } \\
\text { variances } \\
\text { assumed }\end{array}$ & 2.769 & $.135^{* *}$ & 0.559 & 8 & 0.592 & 1.1200 & 2.0050 & -3.5036 & 5.7436 \\
\hline & $\begin{array}{l}\text { Equal vari- } \\
\text { ances not } \\
\text { assumed }\end{array}$ & & & 0.559 & 7.005 & 0.594 & 1.1200 & 2.0050 & -3.6205 & 5.8605 \\
\hline \multirow[t]{2}{*}{$\mathrm{I}-\mathrm{Li}$} & $\begin{array}{c}\text { Equal } \\
\text { variances } \\
\text { assumed }\end{array}$ & 0.058 & $.815^{* *}$ & -0.179 & 8 & 0.863 & -0.4000 & 2.2395 & -5.5642 & 4.7642 \\
\hline & $\begin{array}{l}\text { Equal vari- } \\
\text { ances not } \\
\text { assumed }\end{array}$ & & & -0.179 & 7.876 & 0.863 & -0.4000 & 2.2395 & -5.5783 & 4.7783 \\
\hline \multirow[t]{2}{*}{ B-Sm } & $\begin{array}{c}\text { Equal } \\
\text { variances } \\
\text { assumed }\end{array}$ & 1.576 & $.245^{* *}$ & 0.428 & 8 & 0.680 & 0.7400 & 1.7308 & -3.2512 & 4.7312 \\
\hline & $\begin{array}{l}\text { Equal vari- } \\
\text { ances not } \\
\text { assumed }\end{array}$ & & & 0.428 & 7.504 & 0.681 & 0.7400 & 1.7308 & -3.2976 & 4.7776 \\
\hline \multirow[t]{2}{*}{ Pg-Pg' } & $\begin{array}{c}\text { Equal } \\
\text { variances } \\
\text { assumed }\end{array}$ & 9.068 & $.017^{*}$ & -0.058 & 8 & 0.955 & -0.1000 & 1.7346 & -4.1001 & 3.9001 \\
\hline & $\begin{array}{l}\text { Equal vari- } \\
\text { ances not } \\
\text { assumed }\end{array}$ & & & -0.058 & 5.973 & 0.956 & -0.1000 & 1.7346 & -4.3492 & 4.1492 \\
\hline
\end{tabular}

${ }^{*}$ there is statistical significance seen only in the chin area of Class III as the $p$ value is $<0.05$.

*there is no statistical significance between the other variables in Class III as the p value is $>0.05$. 